\title{
A STUDY OF CUSTOMER SATISFACTION ON ONLINE TRADING SYSTEM APPLICATION OF SECURITIES COMPANY IN INDONESIA USING SERVQUAL
}

\author{
Hery \\ Department of Information Systems \\ Faculty of Computer Science \\ University of Pelita Harapan \\ Jakarta 15811, Indonesia \\ Email: hery_mb@yahoo.com
}

\author{
Riswan Efendi Tarigan \\ Department of Information Systems \\ Faculty of Computer Science \\ University of Pelita Harapan \\ Jakarta 15811, Indonesia \\ Email: re.tarigan@gmail.com
}

\begin{abstract}
The purpose of this study is to measure the service quality of online trading system implemented by PT KDB Daewoo Securities Indonesia. The study is a part of the company efforts to provide the best solution services. The study is performed to determine the influence of service quality factors on the customer satisfaction by means of ServQual method. The method takes into account five independent variables, namely, reliability $\left(X_{1}\right)$, responsiveness $\left(X_{2}\right)$, assurance $\left(X_{3}\right)$, empathy $\left(X_{4}\right)$, and tangibility $\left(X_{5}\right)$. Meanwhile, the customer satisfaction is considered as the dependent variable $(Y)$. The population of of the study is all 67900 online traders at the company and the sample size is 265 traders. The data are collected via questionnaires and interviews. From the study results, we conclude that the five variables have significant influence on the customer satisfaction on the online trading system application at PT KDB Daewoo Securities Indonesia. To improve the customer satisfaction, the company should prioritize the qualityrelated factors, and expand and upgrade the existing facilities and infrastructures.
\end{abstract}

Keywords: Customer Satisfaction; Service Quality; Online Trading

\section{INTRODUCTION}

Currently, rapid technology developments have led many companies to change the way they run their business. A company without the use of technology is assuredly lagging behind in many aspects such as efficiency, connectivity, market expansion, and so forth.

Internet drastically changes the way companies performing their businesses including those companies

Received: February 27, 2015; received in revised form: March 6, 2015; accepted: March 12, 2015; available online: June 17, 2015. in the financial industry [1-4]. The technology developments in the financial sector are rapidly changing the dynamics and transaction processes. In the past, stock trading transactions were made through verbal contacts or by telephone. Customers could choose to meet their brokers or simply call the office from home for transactions. Transactions over the phone could be inefficient because of the potential errors in the communication, the limitation in the customer authentication, the density of telephone lines in the peak trading session and the associated costs [5].

Many financial security companies have adopted information technology to support their online trading systems. PT KDB Daewoo Securities Indonesia, a brokerage firm, has also understood the importance of the online trading system and has launched their own system called Home Online Trading System (HOTS). The online trading system allows traders to enter orders directly into the system through the exchange members' facilities technology such as laptops, personal computers, and mobile phones with the Internet support [6-9].

As a number of the system users have filed complaints and recommendations regarding the system performance, PT KDB Daewoo Securities Indonesia decides to investigate the customer level of satisfaction of the HOTS. Furthermore, as an effort to improve the customer satisfaction level, the company released the HOTS application version 2 in the early of 2009. However, the application has not yet reached the expected 
Cite this article as: Hery and R. E. Tarigan, "A study of customer satisfaction on online trading system application of securities company in Indonesia using servqual," CommIT Journal, vol. 9, no. 1, pp. 19-22, 2015.

results as indicated by the number of customers whom filed complaints regarding the system. Thus, the evaluation of the implementation of online trading system is necessary in order to improve the performance of the company for maintaining the company competitive advantage against its competitors.

Based on the company Standard Operating Procedure (SOP) of handling complaints and service standards anticipated by the company, the number of complaints exceeds the number of anticipated service. The company management realized that the quality of services are not maximal yet. The graphic data of the number of customer complaints about the online trading service system of PT KDB Daewoo Securities Indonesia can be seen in Fig. 1.

With so many existing complaints from customers against the services of the online trading system, PT KDB Daewoo Securities Indonesia afraid that it may have negative impacts, directly or indirectly, to the company. One of the negative impacts is that the poor system performance may spread and result in a negative image painted at the company. Furthermore, the negative image may affect the client trust and the client may switch to their competitors and reducing the company profits.

The management of PT KDB Daewoo Securities Indonesia needs to devise good service management strategies in accordance with customer expectations. Therefore, to determine the factors that lead to customer complaints against the services of online trading system, this study is conducted to study the relation between the online trading service system quality and the customer satisfaction using the ServQual method [10$16]$.

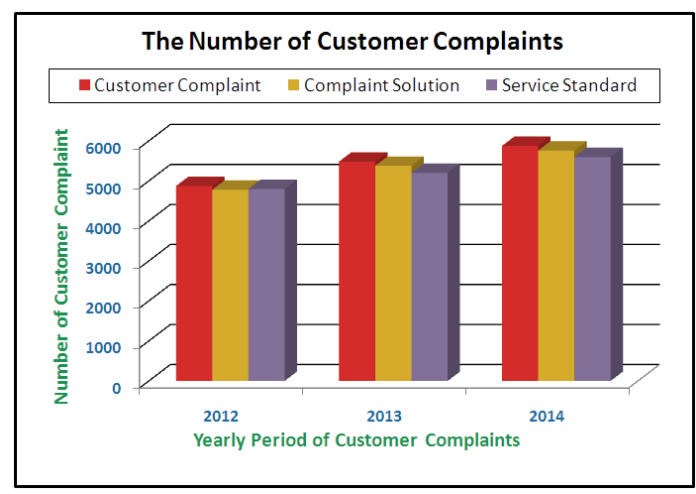

Fig. 1. The Number of Customer Complaints on the Home Online Trading System (HOTS) of PT KDB Daewoo Securities Indonesia During the Period of 2012-2014.

The study framework is that of Service Quality (ServQual) and is adopted from Ref. [17]. The framework is depicted in Fig. 2. After successfully identifying the factors affecting customer satisfaction, a gap analysis is performed to determine the level of the perceived and expected satisfactions. The gap analysis is on the basis of that of Ref. [18-20].

The total number of traders using the system is 67900 traders. At the 5\% error, the sample size of 265 traders is sufficient. The response for each indicator is collected via questionnaires and interviews. The relation between the dependent and independent variables is established by multi-variate regression.

\section{RESULTS AND DISCUSSION}

The established mathematical model describing the customer satisfaction and the service level is of the following:

$$
\begin{aligned}
Y & =0.848+0.160 X_{1}+0.149 X_{2}+0.250 X_{3} \\
& +0.153 X_{4}+0.164 X_{5},
\end{aligned}
$$

where $X_{1}$ denotes reliability, $X_{2}$ denotes responsiveness, $X_{3}$ denotes assurance, $X_{4}$ denotes empathy, and $X_{5}$ denotes tangibility.

Then, the model is evaluated using $F$ test for the global test, $t$ test for the significance of each parameter, and the normality of the model residue. The results are of the following.

The results of the $t$ tests for each model coefficient are shown in Table I. The computed $t$ values for the model coefficient $\beta_{1}, \beta_{2}, \ldots, \beta_{5}$ respectively are 2.183 ( $p$-value $=0.030), 2.159(0.032), 3.746(0.000)$, 3.451 (0.001), and 2.527 (0.012). Because all $p$-values are smaller than 0.05 , we conclude that the variables $X_{1}, X_{2}, \ldots, X_{5}$ are all significant.

The results of the global or simultaneous test are given in Table II. With the value of Sig. of very small

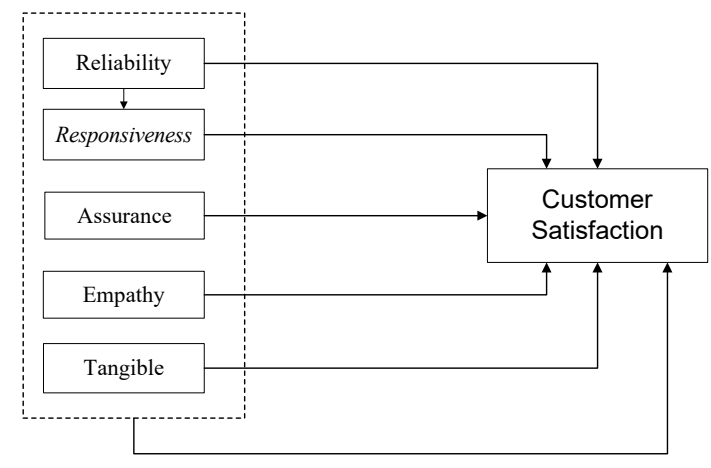

Fig. 2. The ServQualv Framework. 
Cite this article as: Hery and R. E. Tarigan, "A study of customer satisfaction on online trading system application of securities company in Indonesia using servqual," CommIT Journal, vol. 9, no. 1, pp. 19-22, 2015.

(0.00), the test indicates that the five variables are simultaneously influence the customer satisfaction.

The multi-variate regression model is constructed with the assumption that the model residue should be random but distributed following the normal distribution. Figure 3 demonstrates that the current model satisfies the assumption.

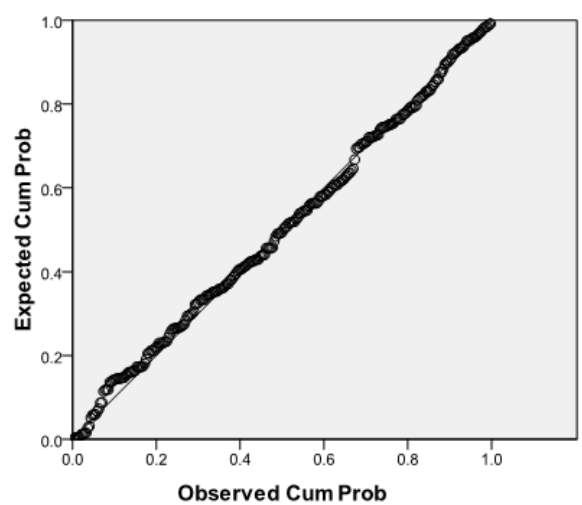

Fig. 3. The QQ-plot to Test the Normality of the Model Residue.

To determine the existing gap between the quality of the online trading service system implemented by PT KDB Daewoo Securities Indonesia on customer satisfaction, the gap analysis is performed and the results are given in Table III. The analysis is performed using the Importance-Performance Analysis (IPA) method [21]. These results show the factors that strongly influence the customer satisfaction and loyalty, and also the factors that require improvement.

TABLE I

The $t$-TEST RESUlTS OF MUlTi-VARIATE REGRESSION.

\begin{tabular}{|c|c|c|c|c|c|}
\hline \multirow[t]{2}{*}{ Model } & \multicolumn{2}{|c|}{ Unstd Coef. } & \multirow{2}{*}{$\frac{\text { Std Coef. }}{\text { Beta }}$} & \multirow[t]{2}{*}{$t$} & \multirow[t]{2}{*}{ Sig. } \\
\hline & B & Std. Error & & & \\
\hline Const. & 0.848 & 0.534 & & 1.587 & 0.114 \\
\hline$X_{1}$ & 0.160 & 0.073 & 0.168 & 2.183 & 0.030 \\
\hline$X_{2}$ & 0.149 & 0.069 & 0.166 & 2.159 & 0.032 \\
\hline$X_{3}$ & 0.250 & 0.067 & 0.274 & 3.746 & 0.000 \\
\hline$X_{4}$ & 0.153 & 0.044 & 0.153 & 3.451 & 0.001 \\
\hline$X_{5}$ & 0.164 & 0.065 & 0.180 & 2.527 & 0.012 \\
\hline
\end{tabular}

TABLE II

The ANOVA TEST RESUlts.

\begin{tabular}{lccccc}
\hline Model & $\sum$ Squares & df & Mean Squares & $F$ & Sig. \\
\hline Reg. & 500.101 & 5 & 100.020 & 88.43 & .00 \\
Res. & 292.941 & 259 & 1.131 & & \\
Total & 793.042 & 264 & & & \\
\hline Reg. = regression, Res. = residual
\end{tabular}

TABLE III

THE RESUlts OF THE GAP ANALYSIS

\begin{tabular}{cccccc}
\hline Variable & Sub-variable & PS & ES & G & Percentage \\
\hline \multirow{2}{*}{$X_{1}$} & $X_{1.1}$ & 4.15 & 3.90 & 0.25 & 94.02 \\
& $X_{1.2}$ & 4.24 & 3.91 & 0.33 & 92.11 \\
\multirow{3}{*}{$X_{2}$} & $X_{1.3}$ & 4.20 & 3.92 & 0.28 & 93.44 \\
& $X_{2.1}$ & 4.87 & 3.88 & 0.99 & 79.73 \\
& $X_{2.2}$ & 4.91 & 3.93 & 0.98 & 80.01 \\
$X_{3}$ & $X_{2.3}$ & 4.82 & 3.81 & 1.01 & 79.07 \\
& $X_{3.1}$ & 4.53 & 4.04 & 0.49 & 89.13 \\
& $X_{3.2}$ & 4.63 & 4.11 & 0.52 & 88.84 \\
$X_{4}$ & $X_{3.3}$ & 4.87 & 3.97 & 0.90 & 81.44 \\
& $X_{4.1}$ & 4.68 & 3.98 & 0.70 & 85.15 \\
\multirow{4}{*}{$X_{5}$} & $X_{4.2}$ & 4.87 & 3.92 & 0.95 & 80.43 \\
& $X_{4.3}$ & 4.62 & 3.97 & 0.65 & 85.84 \\
& $X_{5.1}$ & 4.58 & 4.00 & 0.58 & 87.25 \\
$Y$ & $X_{5.2}$ & 4.76 & 4.08 & 0.68 & 85.78 \\
& $X_{5.3}$ & 4.85 & 4.09 & 0.76 & 84.34 \\
& $Y_{1}$ & 4.28 & 3.68 & 0.60 & 85.88 \\
& $Y_{2}$ & 4.34 & 3.62 & 0.72 & 83.38 \\
& $Y_{3}$ & 4.82 & 4.00 & 0.82 & 82.99 \\
\hline
\end{tabular}

\section{CONCLUSIONS}

The study has shown that the satisfaction of customers in online transactions at PT KDB Daewoo Securities Indonesia is influenced by the quality of services involving the factors of reliability, responsiveness, assurance, empathy, and tangibility. The results indicate that the company should continue to improve the quality of services, especially in the areas of reliability and responsiveness, as well as maintain in the areas of assurance, empathy, and tangibility. As the company has two kinds of products to offer, goods and service, to engage in the service, the company should maximize the relevant factors to achieve the high level of the customer satisfaction. In addition, one additional and important factor that should be improved is the stock transactions. It is necessary to provide a better infrastructure related to the system operations.

\section{REFERENCES}

[1] F. Vakil and F. V. Lu, "The effect of the internet on stock market volume and volatility," Review of Business, vol. 26, no. 3, pp. 26-30, 2005.

[2] R. DeYoung, "The performance of internet-based business models: Evidence from the banking industry*," The Journal of Business, vol. 78, no. 3, pp. 893-948, 2005.

[3] C. Marston and A. Polei, "Corporate reporting on the internet by german companies," International Journal of Accounting Information Systems, vol. 5, no. 3, pp. 285-311, 2004.

[4] D. Buhalis, "eairlines: strategic and tactical use of icts in the airline industry," Information \& Management, vol. 41, no. 7, pp. 805-825, 2004. 
Cite this article as: Hery and R. E. Tarigan, "A study of customer satisfaction on online trading system application of securities company in Indonesia using servqual," CommIT Journal, vol. 9, no. 1, pp. 19-22, 2015.

[5] E. K. Clemons and L. M. Hitt, "The internet and the future of financial services: Transparency, differential pricing and disintermediation," Wharton School Center for Financial Institutions, University of Pennsylvania, Tech. Rep., 2000.

[6] H. Linda, "Home online trading system," Indonesia Stock Journal, vol. 8, pp. 11-15, 2012.

[7] R. S. Wilton and D. L. Silverman, "Electronic trading system featuring arbitrage and third-party credit opportunities," Feb. 11 2003, uS Patent $6,519,574$.

[8] J. B. Skjærseth and J. Wettestad, "Fixing the eu emissions trading system? understanding the post-2012 changes," Global Environmental Politics, vol. 10, no. 4, pp. 101-123, 2010.

[9] J. J. Schott, "Free trade agreements: boon or bane of the world trading system," Free Trade Agreements: US Strategies and Priorities, vol. 3, no. 11, 2004.

[10] J. J. Cronin Jr and S. A. Taylor, "Servperf versus servqual: reconciling performance-based and perceptions-minus-expectations measurement of service quality," The Journal of Marketing, vol. 2, pp. 125-131, 1994.

[11] J. Tribe and T. Snaith, "From servqual to holsat: holiday satisfaction in varadero, cuba," Tourism Management, vol. 19, no. 1, pp. 25-34, 1998.

[12] J. E. Collier and C. C. Bienstock, "A conceptual framework for measuring e-service quality," in Creating and Delivering Value in Marketing. Springer, 2015, pp. 158-162.

[13] Y.-S. Wang and T.-I. Tang, "Assessing customer perceptions of website service quality in digital marketing environments," Journal of Organizational and End User Computing (JOEUC), vol. 15, no. 3, pp. 14-31, 2003.

[14] E. Babakus and M. Inhofe, "Measuring perceived service quality as a multi-attribute attitude," in
Proceedings of the 1993 Academy of Marketing Science (AMS) Annual Conference. Springer, 2015, pp. 376-380.

[15] P. Bharati and A. Chaudhury, "Product customization on the web: an empirical study of factors impacting choiceboard user satisfaction," Bharati, P. and Chaudhury, A.(2006),Product Customization on the Web: An Empirical Study of Factors Impacting Choiceboard User Satisfaction, Information Resources Management Journal, vol. 19, no. 2, pp. 69-81, 2015.

[16] S. A. Kaynama, "A conceptual model to measure service quality of online companies: E-qual," in Proceedings of the 2000 Academy of Marketing Science (AMS) Annual Conference. Springer, 2015, pp. 46-51.

[17] A. Parasuraman, V. A. Zeithaml, and L. L. Berry, "Reassessment of expectations as a comparison standard in measuring service quality: implications for further research," The journal of Marketing, vol. 58, pp. 111-124, 1994.

[18] Y. Ben-Haim, "Info-gap economics," Environmental Management, vol. 87, pp. 443-449, 2010.

[19] S. E. Black and L. M. Lynch, "How to compete: the impact of workplace practices and information technology on productivity," Review of Economics and statistics, vol. 83, no. 3, pp. 434445, 2001.

[20] M. D. Chinn and R. W. Fairlie, "The determinants of the global digital divide: a cross-country analysis of computer and internet penetration," Oxford Economic Papers, 2006.

[21] B. N. Sethna, "Extensions and testing of importance-performance analysis," in Proceedings of the 1982 Academy of Marketing Science (AMS) Annual Conference. Springer, 2015, pp. 327-331. 